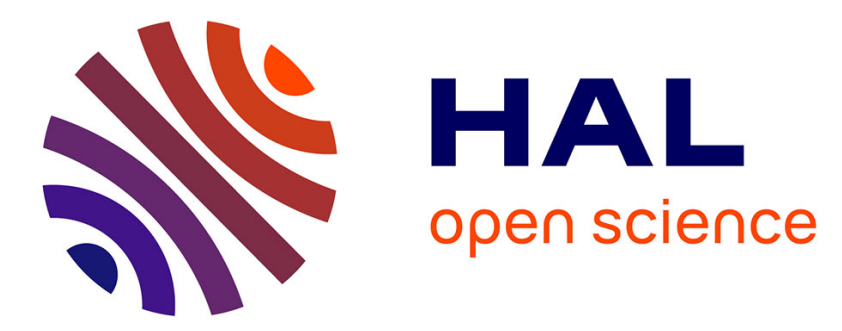

\title{
Improvising Intermodality and Multimodality. Empirical Findings for Lomé, Togo
}

Lourdes Diaz Olvera, Assogba Guezere, Didier Plat, Pascal Pochet

\section{To cite this version:}

Lourdes Diaz Olvera, Assogba Guezere, Didier Plat, Pascal Pochet. Improvising Intermodality and Multimodality. Empirical Findings for Lomé, Togo. Case Studies on Transport Policy, 2015, 3, pp.459-467. 10.1016/j.cstp.2015.10.001 . halshs-01246819

\section{HAL Id: halshs-01246819 \\ https://shs.hal.science/halshs-01246819}

Submitted on 3 May 2016

HAL is a multi-disciplinary open access archive for the deposit and dissemination of scientific research documents, whether they are published or not. The documents may come from teaching and research institutions in France or abroad, or from public or private research centers.
L'archive ouverte pluridisciplinaire HAL, est destinée au dépôt et à la diffusion de documents scientifiques de niveau recherche, publiés ou non, émanant des établissements d'enseignement et de recherche français ou étrangers, des laboratoires publics ou privés.

\section{(c)(1)}

Distributed under a Creative Commons Attribution| 4.0 International License 
Diaz Olvera L., Guézéré A., Plat D., Pochet P. (2015), Improvising intermodality and multimodality. Empirical findings for Lomé, Togo, Case Studies on Transport Policy, Vol. 3, pp. 459-467

\title{
Improvising intermodality and multimodality. Empirical findings for Lomé, Togo
}

\author{
Lourdes Diaz Olvera \\ Laboratoire d’Economie des Transports, Université de Lyon (ENTPE, Université Lumière Lyon 2, \\ CNRS), Rue Maurice Audin, 69518 Vaulx-en -Velin Cedex, France. Tel.: +33 47204 7244, \\ lourdes.diaz-olvera@entpe.fr \\ Corresponding author \\ Assogba Guézéré \\ Department of Geography, University of Kara, B. P. 43, Kara, Togo. Tel.: +228 9028 0603, \\ guezereassogba@gmail.com or guezere1970@yahoo.fr \\ Didier Plat \\ Laboratoire d'Economie des Transports, Université de Lyon (ENTPE, Université Lumière Lyon 2, \\ CNRS), Rue Maurice Audin, 69518 Vaulx-en-Velin Cedex, France. \\ Tel.: +33 4 7204 7047, didier.plat@entpe.fr \\ Pascal Pochet \\ Laboratoire d'Economie des Transports, Université de Lyon (ENTPE, Université Lumière Lyon 2, \\ CNRS), Rue Maurice Audin, 69518 Vaulx-en-Velin Cedex, France. Tel.: +33 47204 7741, \\ pascal.pochet@entpe.fr
}

Abstract: While achieving integrated transport is an increasingly important policy goal in the cities of the North, it is of little concern to African decision-makers. Nevertheless, the scarcity of transport has prompted African city-dwellers to create "de facto" integration, which has, until now, received little scholarly attention. This paper describes the intermodal and multimodal practices of the inhabitants of Lomé, the capital of Togo, where the motorbike taxi plays a dominant role. Intermodality, i.e. the use of at least two transport modes in the course of a single trip, allows individuals to travel throughout the city but requires trade-offs between transport cost, duration and physically exhausting conditions. Multimodality, which is defined as the use of a different mode or combination of modes for outbound and return trips, is observed to some extent among the working population but even more amongst schoolchildren, usually in order to reduce the cost of transport. The consequences of individuals" "de facto" intermodal and multimodal practices in terms of mobility and money and time budgets highlight the strategic importance of formal transport integration for African city-dwellers.

Keywords: intermodality, multimodality, transport integration, mobility, motorbike taxis, Lomé 


\section{Introduction}

In the cities of the North, the integration of the different types of passenger transport services to form a coherent system is the subject of much concern and an increasing number of applications. Integration sets out to enhance simultaneously the sustainability of transport systems and accessibility which allows the provision of good transport services at a low cost. At a fundamental level, integration can be seen as a set of technical and organizational tools that seek to make the best use of existing transportation networks, by combining them with the use of personal modes when this is possible. Integration may also take more ambitious forms and attempt to align transport policies with those for other sectors.

However, in the cities of sub-Saharan Africa, where walking is the rule and the majority of motorised trips are made by informal public transport, integration arouses very little interest on the part of either the public authorities or the operators. Nevertheless, when we examine transport demand, daily travel includes practices which can be regarded as "de facto" integration, instituted by the users themselves: the successive use of several transport modes in the course of the same trip (which may include long segments on foot), the use of different modes for the outbound and return journeys.

This paper sets out to improve our understanding of the "de facto" integration of daily travel in the cities of sub-Saharan Africa through the study case of Lomé, the capital of Togo. It examines the modal practices of public transport users. How do citizens use the different transport modes on a day-to-day basis? How do they combine them in order to reach their destination? Do they use different modes or sequences of modes for their outbound and return trips? How does their choice of transport mode affect their travel times and their monetary expenditure on daily travel?

The analyses presented in this paper are based on empirical data collected in the course of a survey conducted in Lomé in late 2011. During the survey, 1228 individuals who were travelling in the conurbation were asked to describe their current trip, their customary practices when travelling from home to work or school and back, the availability of personal vehicles, and the accessibility of their home. The conventional data were elicited about their trips: the origin and destination, the modes used, the trip purpose, the price paid and the duration of the trip. It was consequently possible to carry out detailed analysis of modal choice, the price/travel time trade-offs, the difficulties they experienced and the way they adapted to them.

Section 1 deals with the different types of transport integration and defines the concepts of intermodality and multimodality as we have used them in this paper. Section 2 describes the study area, the survey methodology and the data set. Intermodal trips are analysed in Section 3 , taking account of the combination of modes and the duration, distance and cost of the trip. Section 4 sheds light on multimodal practices by comparing the combinations of modes used during the outbound and return trips for work- and school-related trips. These analyses reveal the additional money and time costs incurred as a result of such intermodal and multimodal practices which are improvised by users in the absence of any formal support from the transport sector. The conclusion highlights the need for formal transport integration in order to improve the travel conditions in sub-Saharan African cities.

\section{From transport integration to intermodality and multimodality}

The public authorities in the developed world advocate transport policies that are based on integration because of two major factors: the urgent need to limit car traffic in order to create 
more sustainable cities and the limited funding available for public transport as a result of the financial crisis. However, the term transport integration may refer either to highly operational measures focused on transport supply or to strategic matters that involve comprehensive public policies (May et al., 2006). It is thus important to distinguish between different forms of transport integration (Potter and Skinner, 2000; Viegas, 2004). The first rung of an integrated transport system is internal integration, which sets out to achieve an internally consistent transport system (Givonni and Banister, 2010; Preston, 2010). The second rung aims to integrate transport policies and land-use. Finally, the third rung attempts to harmonise multi-sectoral policies (for example transport and local economic development, transport and access to healthcare). In this paper we shall deal only with internal integration.

Internal transport integration may be either modal or functional (Potter and Skinner, 2000). Modal integration aims to facilitate transfers between different transport modes by improving interchange points and synchronizing the timetables of different services. Functional integration involves integrating pricing so that a change in transport mode does not generate potentially dissuasive additional user costs. In both cases the primary aim is to promote the successive use of several transport modes during the same trip (Potter and Skinner, 2000; Hine and Scott, 2000; Gorter et al., 2000; Martens, 2004, 2007). Such successive use can be referred to by the terms “'multimodal' and 'intermodal', which are used interchangeably" (Givoni and Banister, 2010: 5). In other cases multimodality refers to the use of different transport modes at different times of the day or the week, depending on the trip purpose or the location of the destination (Nobis, 2007; Parkhurst et al., 2012). The ability to distinguish between intermodality and multimodality would seem to be important when analysing daily mobility, as they result from partially different modal choices and behavioural adaptations in response to constraints. In this paper we shall use the term intermodality to describe the chaining of transport modes within the same trip and multimodality to describe differences in modal use between outbound and return trips.

It is important to make a distinction between intermodality and multimodality as the corresponding data are collected and processed in a different manner. Multimodality is easier to identify by observing the sequence of trips, but to measure it accurately data must be collected over a long enough period of time. The underestimation of intermodality can be significant because conventional surveys pay little attention to short walking trips and underestimate the role of walking segments during mechanized trips (Behrens et al., 2004; Clifton and Muhs, 2012). Trips in which mechanized modes and walking are combined "[...] are generally not regarded as intermodal trips in the technological sense, nor within the consciousness of most travellers, transport planners and politicians" (Parkhurst et al. 2012: 309). As a consequence, the role of walking in the daily travel of city-dwellers is seriously underestimated. In a study of the Netherlands, Rietveld (2000) has shown that walking becomes the most used mode when pedestrian segments are considered, its share rising from 18 to $59 \%$. In the cities of sub-Saharan Africa, walking is not only the sole mode of transport for many trips, it may also be the only possible way of reaching public transport stops, as in Douala or Conakry (Sitrass, 2004a, 2004b). In Douala, for example, trips in which a single public transport segment is combined with at least one walking segment lasting more than 5 minutes are three times more numerous than trips that require the successive use of several public transport vehicles. These commonplace practices show that urban residents are genuinely implementing modal integration.

Nevertheless, in the cities of developing countries, which are highly fragmented (Balbo and Navez-Bouchanine, 1995) and whose transport systems rely essentially on informal operators (Cervero and Golub, 2007), thinking about intermodality in transport policies is at a much less advanced stage (Yeh, 2008; Rivasplata, 2001). In African cities, urban transport suffers from 
a lack of organization and regulation which pushes informal operators into fierce competition with each other (Cervero, 2000). However, this situation does not exclude the possibility of transport modes and operators working together. In order to ensure their business remains profitable, operators must provide a minimum number of interconnections between public transport vehicles serving different routes. The informal sector's ability to organize itself leads to possible connections between different transport modes, as studied by Audard et al. (2012) in Brazzaville. The presence of the different transport modes at major stops and terminals means that these operate, de facto, as multimodal interchanges.

Intermodal trips are still complicated and costly. Public transport users in cities such as Conakry, Douala and Nairobi all suffer from the poor organization of passenger pick-up and drop-off and the shortening and division of routes into fare sections. They have to make unplanned walking segments or change vehicle, which increases the cost of travel (Sitrass, 2004a, 2004b; McCormick et al., 2013). Likewise, in Dar es Salaam, passengers frequently need to chain several dala dala journeys in order to travel to work, paying each time they board a vehicle, which makes commuting expensive (Nkurunziza et al., 2012). The marked sprawl that affects African cities and the frequent need to use several vehicles to reach a destination make transport an increasingly expensive item of household expenditure and increase transport time budgets, particularly for workers and students living in the outskirts.

A low level of modal integration and an absence of functional integration are thus the general rule in African cities. The blossoming of Bus Rapid Transit projects in many cities has scarcely stimulated any debate on the need for transport sector integration that includes informal transport (Behrens et al., 2012). Formal modal integration set up by the authorities seems to be fairly rare, in particular because interchange stations are more a setting for confrontation between stakeholders and for social and political conflict than genuine intermodal interchange (Lombard and Steck, 2004; Ndiaye and Tremblay, 2009). The introduction of integrated fares seems unattainable in the short or medium term, as a result of the fragmentation of the sector and the limited regulatory capacities of the public authorities. While a traveller may negotiate the fare of each successive leg of a trip, this is not the case at all times and for all destinations and, obviously, the amount of the fare does not take account of the other segments in the trip or the user's ability to pay. Salon and Gulyani (2010) have shown that, in the case of Nairobi, affordability, more than transport provision, hinders access to public transport for poor slum-dwellers. However a close examination of daily mobility in Lomé shows that intermodal and multimodal practices are improvised, but widespread.

\section{Study area and empirical material}

The conurbation of Lomé had a population of 1.5 million in 2010, which amounts to slightly less than a quarter of the resident population of Togo (République Togolaise, 2011). Administratively, it is divided into a central municipality, the city of Lomé proper, which is home to $57 \%$ of the conurbation's population, and seven peripheral cantons. Urban sprawl has been restricted to the west by the border with Ghana and to the south by the Atlantic Ocean (Figure 1). The most important zones for business activities and jobs are near the ocean: the autonomous port of Lomé which handles four-fifths of Togo's foreign trade, the administrative district, and the central market of Adawlato. The network of main roads consists essentially of a few radial roads and a ring road, which are all asphalt-paved. The rest of the road network near the centre and in the outskirts consists of sand or earth roads some of which are completely flooded in the rainy season. During this period they turn into genuine 
swamps making motor vehicle travel difficult or even impossible. The general state of the road network therefore limits the possibilities for travel, especially by four-wheeled vehicle.

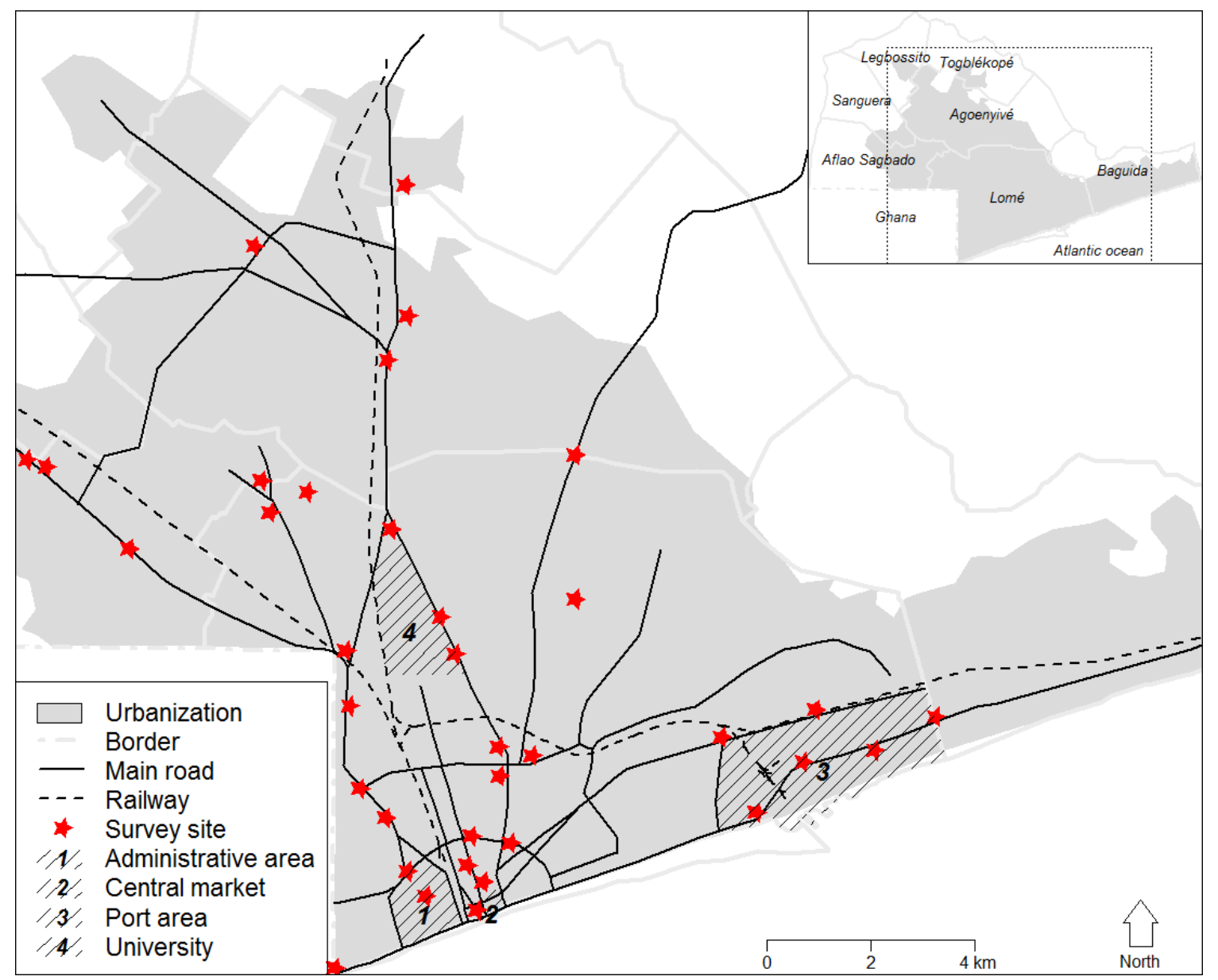

Figure 1. The conurbation of Lomé: administrative areas, main road network and business zones, and survey locations

As in other West African cities, household ownership of personal vehicles is low in Lomé (Diaz Olvera et al., 2013). In 2011, public transport supply was provided essentially by shared taxis and motorbike taxis, with the minor presence of the few buses on the "experimental route" operated by Sotral, a company set up in 2007. Shared taxis are saloon cars which either cruise for clients or operate on fixed routes which usually start from the central market. In the early 1990s these were the only taxis in Lomé, but they were rapidly replaced by motorbike taxis which have now become the dominant form of public transport (Guézéré, 2012). The oleyias or zemidjans, as motorbike taxis are known locally, are thus the main suppliers of public transport, both in the city centre and in the outskirts. We conducted a survey in 2011 to study how the inhabitants of Lomé use the different public transport modes and to identify intermodal and multimodal practices.

The survey covered individuals of 13 years of age and over who were travelling in the conurbation, and focused on public transport users. It was carried out during a week (excluding Sunday) in public space at 10 key points distributed throughout the conurbation. A total of 1,220 individuals, $68 \%$ of whom were economically active, were asked to give details about their socio-economic characteristics, the trip they were making and their habits with regard to work- or school-related trips. For the trip the individual was making when he/she 
was intercepted for the interview, information was collected about all the modes used during the trip, including all walking segments of at least 10 minutes made before or after travel in public transport vehicles. In the case of individuals' customary work- and school-related trips, the survey also collected information on the combinations of transport modes used, distinguishing between outbound and return trips.

The purpose of the survey was to identify the combination of transport modes used in daily travel and did not seek to be statistically representative of the population of Lomé. Individuals who did not travel on the survey day were not included and members of the working population had a higher probability of being interviewed. The underestimation of pedestrian trips, an essential component of daily mobility in African cities, was also a methodological choice. The fact that the interviews were conducted in the vicinity of key transport nodes meant that internal trips within the individuals' residential district, which are almost always on foot, were virtually excluded from the survey. This choice does not interfere with the survey's goal. After consolidation of the collected data we were left with a sample of 3,984 trips to study the intermodal and multimodal practices of urban transport users.

\section{Chaining different modes: a costly necessity}

The modal distribution of "current" trips ${ }^{1}$ reflects the domination of motorbike taxis (Table 1). The oleyias are used in slightly more than eight out of every ten public transport trips ${ }^{2}$. However, their share drops when intermodality is taken into account. Less than a quarter of the trips in which oleyias are involved are intermodal while this applies to more than half of the trips involving shared taxis. These figures reveal two important types of intermodality in Lomé, each of which applies to more than $10 \%$ of public transport trips:

- intermodality between public transport and walking, i.e. the combination of one public transport leg and one (rarely two) pedestrian legs lasting at least 10 mins;

- intermodality between public transport modes, i.e. the combination of two (rarely three) public transport legs (usually by oleyia and shared taxi), sometimes with a pedestrian leg lasting at least 10 mins.

Table 1. Distribution of public transport trips in Lomé according to type of mode

\begin{tabular}{lccc}
\hline & $\begin{array}{c}\text { \% of total public } \\
\text { transport trips }\end{array}$ & $\begin{array}{r}\text { \% of total } \\
\text { oleyia trips }\end{array}$ & $\begin{array}{c}\text { \% of total } \\
\text { shared taxi trips }\end{array}$ \\
\hline Oleyia & 64.6 & 77.8 & \\
Oleyia + Walking >=10 mins & 7.6 & 9.1 & \\
Oleyia + Other Mode & 1.6 & 2.0 & 36.3 \\
\hline Oleyia + Shared taxi & 9.2 & 11.1 & 47.8 \\
\hline Shared taxi & 12.1 & & \\
Shared taxi + Walking >=10 mins & 3.9 & & \\
Shared taxi + Other mode & 0.1 & \\
\hline Other public transport modes* & 0.9 & 100.0 \\
\hline Total & 100.0 & \\
\hline * Mainly Sotral buses and buses for university students. & & \\
Source: 2011 Lomé Survey &
\end{tabular}

\footnotetext{
${ }^{1}$ The "current” trip is the trip the respondent was making when he or she was intercepted for the survey.

${ }^{2}$ If we consider legs rather than trips, oleyias accounted for $76 \%$ of the legs in "current" public transport trips and $83 \%$ of the public transport legs made in the last seven days.
} 
Intermodal practices involving a personal motorbike and a public transport mode are fairly rare: individuals who get a ride on a friend's motorbike in order to shorten the distance and reduce the cost of the rest of the trip on public transport, or motorbike drivers who park their vehicle and complete their trip to the city centre by motorbike taxi because they are afraid of the traffic or the theft of their machine. The absence of intermodal practices involving a private car is simply due to the low rate of car ownership.

\subsection{Intermodality is valuable}

The making of intermodal trips is closely linked to the distance covered. They are made on the longest and most complex trips between the central municipality of Lomé and its outskirts - the cantons in the conurbation (Figure 2). Trips which combine oleyia and shared taxi are particularly common. On the other hand, the proportion of intermodal trips becomes much smaller for internal trips within the municipality of Lomé or its peripheral cantons. In the outskirts, the higher frequency with which oleyia use requires walking as an access or egress mode is explained by the low residential densities, the limitations of the road network and the longer distances between the loading point and one's home.

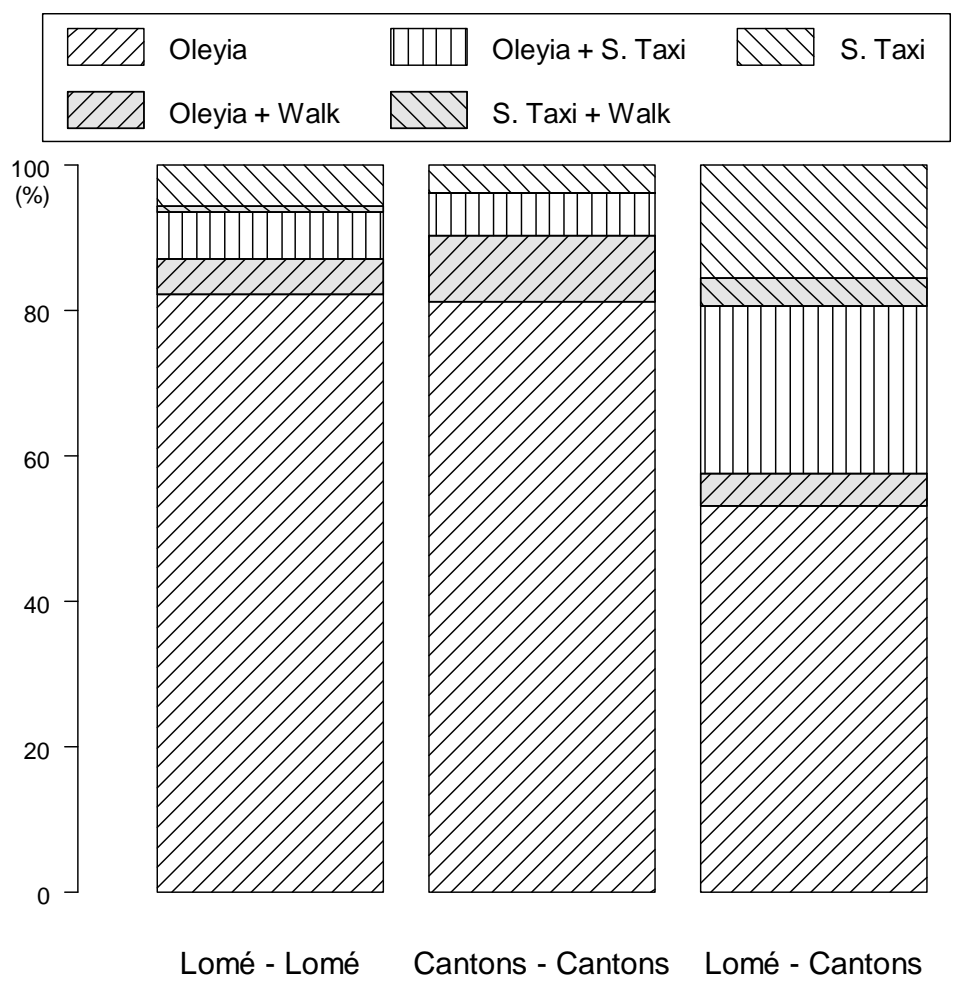

Figure 2. Distribution of public transport trips in Lomé according to origin and destination Note: S. Taxi=Shared taxi

Source: 2011 Lomé Survey

The boxplot of travel distances ${ }^{3}$ show that short and medium distance trips are the market segment for which the use of oleyias is the most common (Fig. 3a). Three-quarters of all oleyia trips, with or without the use of walking as a feeder mode, involve distances of under

\footnotetext{
${ }^{3}$ The distance used here is the crow's flight distance between the centroids of the origin and destination zones.
} 
about 4 kilometres. Shared-taxi use, whether or not it is combined with an oleyia involves longer distances. However, oleyias dominate transport supply to such an extent that they are still used for more than half the trips that exceed $5 \mathrm{~km}$. A similar hierarchy is apparent with increasing trip duration (Figure 3b). The oleyia, with or without the use of walking as a feeder mode, gradually gives way to the shared taxi, and then to the combined use of the oleyia and the shared taxi.
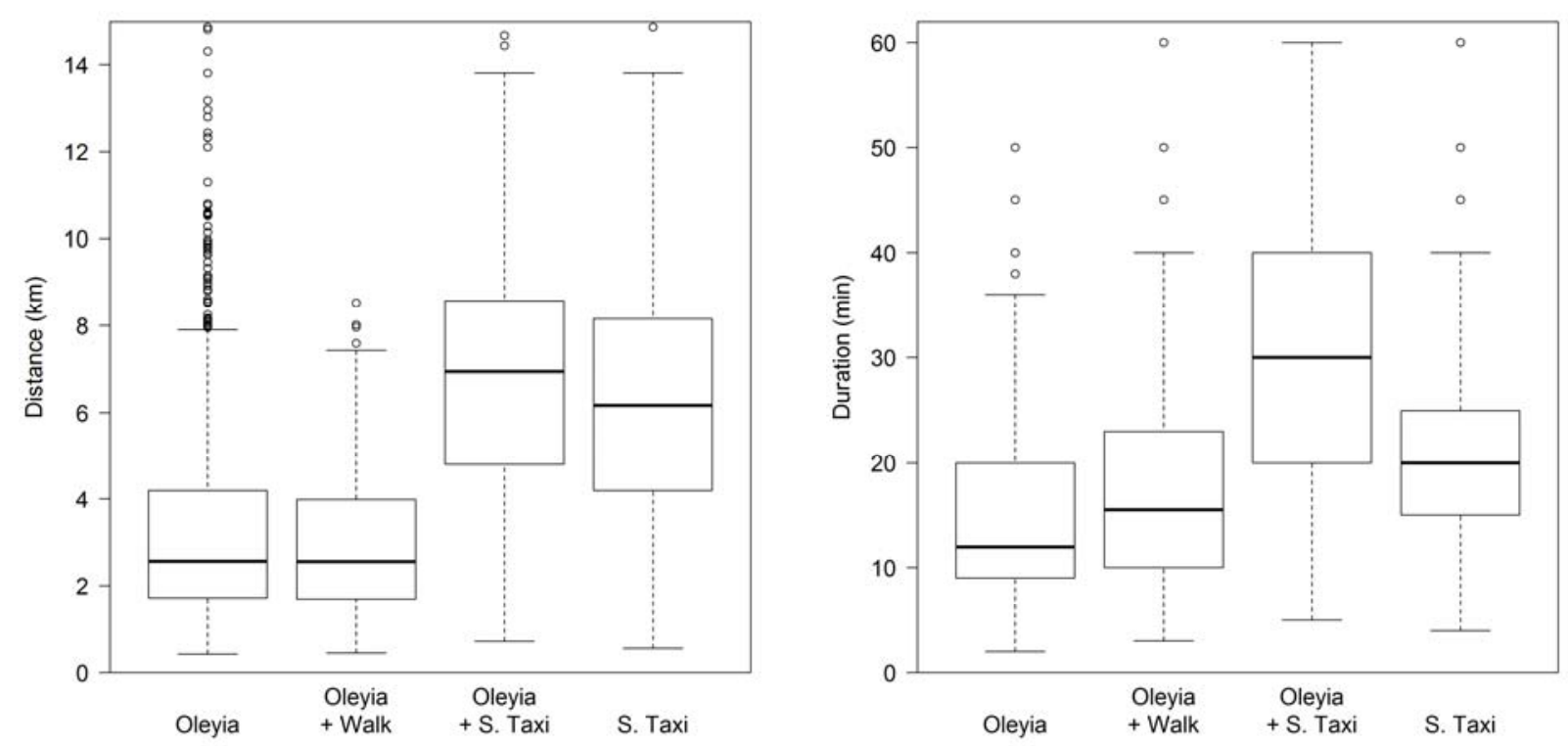

Figures 3a and 3b. Boxplots of trip distance and duration by public transport mode in Lomé Note: S. Taxi=Shared taxi Source: 2011 Lomé Survey

Figure 4 presents the travel domains of the different public transport modes in Lomé, in terms of travel distance and travel time. Logically, adding a walking segment at the beginning or end of an oleyia trip results in a lengthening of door-to-door travel times, but this use of walking for part of the trip does not increase the travel domain of the motorbike taxi in terms of distance. In distance terms, the travel domains of shared taxis and the combination of shared taxi and oleyia are fairly similar: $50 \%$ of all the trips are between 4 and $8 \mathrm{~km}$ in the case of the first and 50\% are between 5 and $9 \mathrm{~km}$ in the case of the second. However, in terms of duration, intermodal oleyia-shared taxi trips often take twice as long, often lasting $40 \mathrm{mn}$.

Previous research on daily mobility conducted in other cities of sub-Saharan Africa show the way an individual's neighbourhood and its immediate vicinity dominate the spatial distribution of daily trips, but also the need to travel throughout the metropolitan area due to the functional specialization of urban areas (Diaz Olvera et al., 2013). The results given above for Lomé show that intermodal combinations, especially those that involve more than one public transport mode, make it possible for city dwellers to travel to parts of the city that are far from their home. In spite of the fact that transport services are fragmented and uncoordinated, intermodality is valuable for city-dwellers... but it comes at a price. 


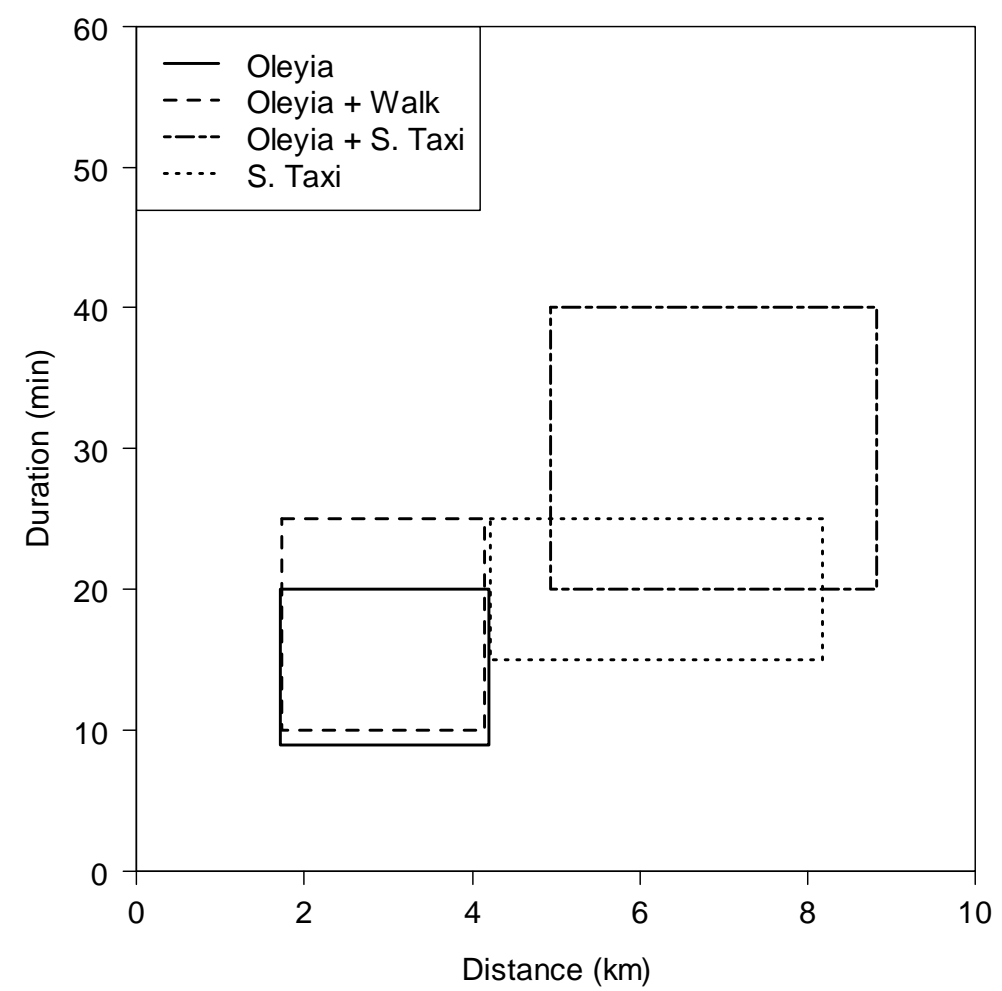

Figure 4. The travel domains of public transport modes in Lomé

Interpretation example: $50 \%$ of the oleyia trips involve a crow's flight distance of between 1.7 and $4.2 \mathrm{~km} ; 50 \%$ have a duration of between 9 and 20 min.

S. Taxi=Shared taxi

Source: 2011 Lomé Survey

\subsection{Intermodality is costly}

The fragmented nature of public transport supply and the fact that the fares charged by informal operators are not controlled mean that fares increase automatically with distance, even if negotiation between the driver and the passenger is often possible leading to variations in the price charged for a given distance (Guézéré, 2008). Figure 5a explains why the oleyia, when used on its own is above all used for short and medium distances. On average, it is less expensive than the other modes or modal combinations up to a crow's flight distance of $2.5 \mathrm{~km}$, after which it is increasingly out-priced by the shared taxi. Above a distance of $6.5 \mathrm{~km}$, oleyia fares are barely lower than the cost of combined use of the oleyia and the shared taxi. This notwithstanding, the conditions that apply to the use of different modes allow us to see why motorbike taxis are often perceived as inexpensive. If we consider the median trip distance for each mode, the median oleyia trip costs under 200 CFA Francs $\left(0.30 €^{4}\right)$, that by shared taxi costs 250 CFA Francs $(0.38 €)$ and that by oleyia and shared taxi combined, 420 CFA Francs (0.64 €; see Figure 5a).

Intermodal trips that involve the successive use of an oleyia and a shared taxi are systematically more expensive because of the summing of the costs for each mode. The resulting expenditure is a considerable drain on household budgets as we can gauge from two straightforward comparisons. First, the median cost of a trip, 420 CFA Francs $(0.64 €)$ is

\footnotetext{
${ }^{4} 100$ CFA Francs=0.152 Euros.
} 
almost equivalent to the price of a bowl of maize that provides a meal for 8 to 10 people $\mathrm{e}^{5}$. Second, a worker on the minimum wage (28,000 CFA Francs, 42.7 $€$ ) who travels from home to work and back by oleyia and shared taxi twenty times a month would only have 11,000 CFA Francs (16.8 €) per month left to spend on other items, including food and housing. These estimations, even though they only refer to hypothetical situations, show the level of constraints such modal practices can generate when they are repeated frequently. This helps us understand why, in order to reduce the cost of their daily travel, citizens are attracted to the other main intermodal strategy based on combining the oleyia and walking (Figures 5a and 5b). The cost differential between the two types of intermodal trips (oleyia combined with shared taxis or with walking) increases very rapidly once the trip duration exceeds 20 mins.
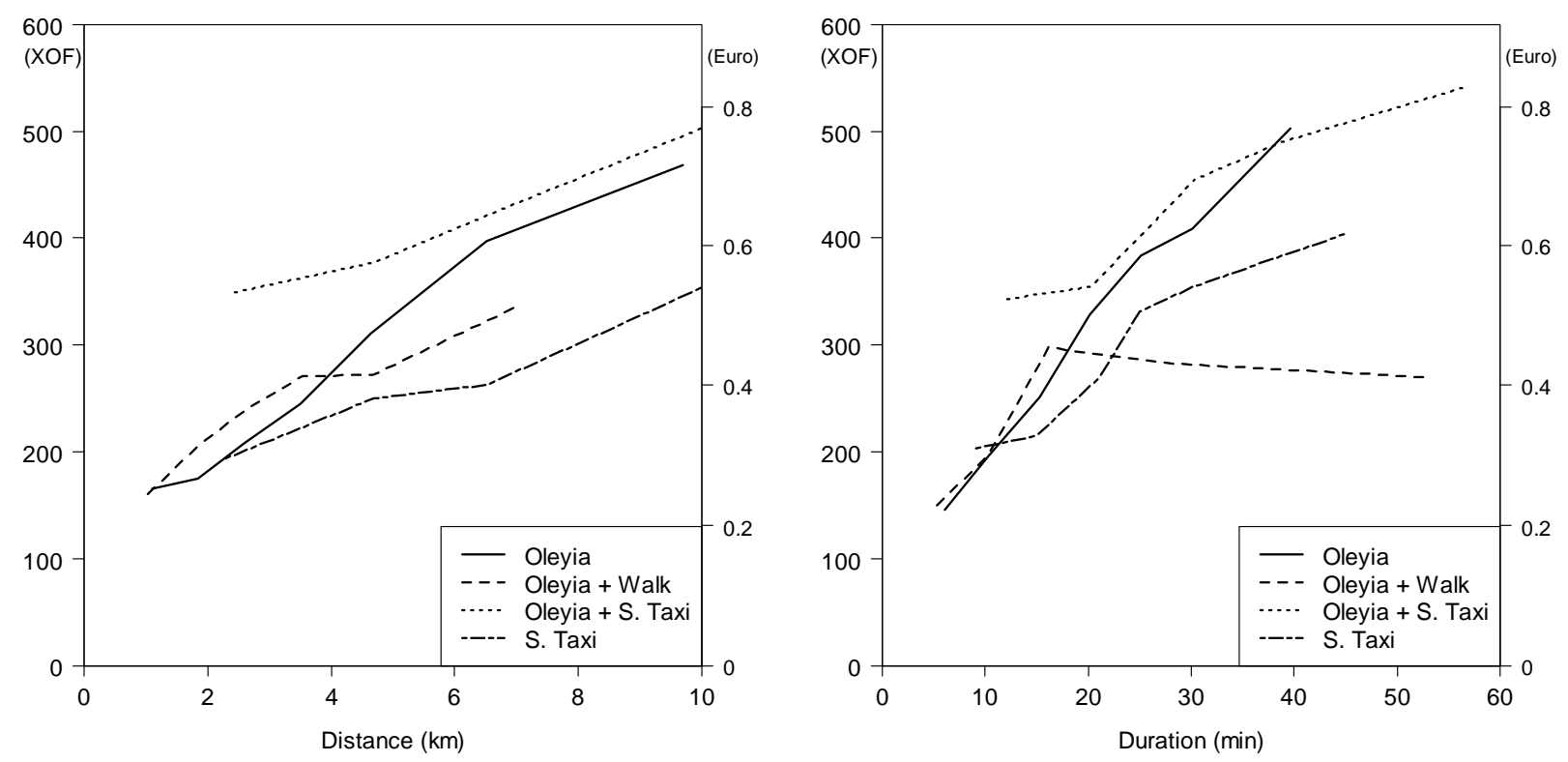

Figures 5a and 5b. Price according to trip distance and duration on public transport in Lomé Note: XOF=CFA Francs. 100 CFA Francs=0.152 Euros. S. Taxi=Shared taxi Source: 2011 Lomé Survey

Walking slightly flattens the price-distance curve. However, this statement needs some qualification. On the one hand, once the distance exceeds $3.5 \mathrm{~km}$, the fare for an oleyia + walking trip increases much more slowly with distance than the fare for a trip by oleyia on its own which becomes more expensive once the distance exceeds $4 \mathrm{~km}$ (Figure 5a). On the other hand, the price-trip duration curve confirms that the way to reduce the cost of oleyia trips is to combine them with walking (Figure 5b). Walking has two different functions in intermodal trips in Lomé:

- as a feeder mode, in order to get to the nearest oleyia loading point. This practice has little impact on the distances covered or the cost of transport. It has more severe consequences for persons who live in the outskirts. In the city centre there is always an oleyia station very close to an individual's home. However, in the outskirts one respondent in ten had at least a ten minute walk to reach one, and this proportion may reach one in five in the most peripheral cantons.

\footnotetext{
${ }^{5}$ Based on our field observations at the time of the survey.
} 
- as a partial substitute for public transport use, to shorten the motorized segment of the trip so as to limit the cost or because no motorbike taxi is available, for example in distant or reputedly dangerous areas, particularly at night. Walking does not alter the total trip distance but it has a real impact on the relationship between the price and the trip duration because as the total duration of the trip increases the expenditure tends to stabilize. Walking implies however a greater physical effort and discomfort.

This dual function of walking in intermodal trips obviously goes hand in hand with a considerable reduction in speed, as can be seen for oleyia + walk intermodal trips (Table 2). The outcome is a marked deterioration in the overall performance of the intermodal combination when this is measured by the price/speed ratio. A similar, but even more marked, deterioration is observed in the case of the intermodal combination oleyia + shared taxi. While this combination is as fast as using a motorbike taxi on its own, it cannot reach the speed of shared taxis used on their own. The price/speed ratio is roughly twice as high for an oleyia + shared taxi intermodal trip than when the two modes are used separately.

Table 2. Median speed and price estimates for public transport modes, in Lomé

\begin{tabular}{|c|c|c|c|c|}
\hline & Oleyia & $\begin{array}{l}\text { Oleyia + } \\
\text { Walk }\end{array}$ & $\begin{array}{l}\text { Oleyia }+ \\
\text { Shared Taxi }\end{array}$ & Shared Taxi \\
\hline Median Speed (km/h) & 14.2 & 10.5 & 14.9 & 17.7 \\
\hline $\begin{array}{r}\text { Median Price FCFA } \\
\text { (Euro) }\end{array}$ & $\begin{array}{l}200 \\
(0.30)\end{array}$ & $\begin{array}{l}200 \\
(0.30)\end{array}$ & $\begin{array}{l}450 \\
(0.69)\end{array}$ & $\begin{array}{l}300 \\
(0.46)\end{array}$ \\
\hline $\begin{array}{l}\text { Median Price / Median Speed } \\
\text { FCFA / }(\mathrm{km} / \mathrm{h}) \\
(\text { Euro / }(\mathrm{km} / \mathrm{h}))\end{array}$ & $\begin{array}{l}14.1 \\
0.0215\end{array}$ & $\begin{array}{l}19.0 \\
0.0290\end{array}$ & $\begin{array}{l}30.2 \\
0.0460\end{array}$ & $\begin{array}{l}16.9 \\
0.0258\end{array}$ \\
\hline
\end{tabular}

Source: 2011 Lomé Survey

City-dwellers can also adapt to the major constraints that restrict their travel on public transport by using a different mode or combination of modes for their outbound and return journey. A description of multimodal practices provides a complementary insight into the use of walking to partially replace public transport modes.

\section{Exploring different possibilities to be able to travel}

The Lomé survey provides information about the outbound and return trips of respondents' customary home-work and home-school mobility (locations of home and work or school, transport mode or sequence of modes, duration and cost). The survey methodology was not intended to capture occasional multimodal practices but customary ones. It is therefore likely that it underestimates the variability between outbound and return trip.

According to the usual practices reported by the respondents, the return trip is frequently different from the outbound trip. Less than three-quarters of home-work trips and only half of home-school trips have outbound and return trips that are strictly identical in terms of mode, duration and price (Table 3). When the outbound and return trips differ we can identify two main types: those for which the modal choice is the same but the price and/or duration differs and those in which modal use differs. The size of these two categories is similar for the working population, but the second category is much more frequent in the case of schoolchildren and students. 
When individuals use the same modes for both directions of their trip, changes in travel conditions are more the outcome of the lower availability or lower modal efficiency than a price-time trade-off. Amongst the working population, in almost all cases the situation is worse on the return trip either because of longer durations or higher costs. The same applies to schoolchildren and students, mainly due to longer durations.

The use of different modes on the return trip is either due to price-time trade-offs because time constraints are less pressing after work or school or because the operating conditions of public transport change according to the time of day. When a different mode is used for the return trip, the duration and cost of the trip change. In the case of half of the workers and three-quarters of the schoolchildren and students, the changes result in less expensive travel on the return trip and longer durations because individuals walk part of the way. More expensive return journeys are considerably more frequent among workers than young people in education. The difference between the two groups is due to the low personal incomes of the latter which puts them under even greater pressure to limit their expenditure.

Table 3. Comparisons between customary outbound and return trips for work and school in Lomé according to mode, trip duration and cost (\%)

\begin{tabular}{|c|c|c|}
\hline Mode(s), Duration, Cost & Home - Work & Home - School \\
\hline $\begin{array}{l}\text { Identical outbound and return trips } \\
\text { (same mode(s), duration and cost) }\end{array}$ & 71 & 52 \\
\hline $\begin{array}{l}\text { Same mode(s), different duration and/or cost for return } \\
\text { trip }\end{array}$ & 14 & 17 \\
\hline Longer duration, same cost & 56 & 75 \\
\hline Same duration, more expensive & 30 & 13 \\
\hline Other cases & 14 & 12 \\
\hline Different mode(s) for return trip & 15 & 31 \\
\hline Longer duration, less expensive & 44 & 64 \\
\hline Shorter duration, more expensive & 24 & 5 \\
\hline Longer duration, more expensive & 11 & 5 \\
\hline Other cases & 21 & 26 \\
\hline
\end{tabular}

Source: 2011 Lomé Survey

These multimodal strategies implemented by the inhabitants of Lomé are consistent with what has been observed in other African cities during exceptional events that interfere with customary practices and reveal their underlying rationale. For example, in Douala, between 2003 and 2005, the repair of the only bridge over the Wouri, which connects the right bank to the left bank where the principal urban facilities are located, disrupted the travel of residents crossing the river. The banning of motorbike taxis and shared taxis from the area where the works were taking place and the introduction of a pay bus to cross the river led passengers to adopt a variety of tactics to minimize the rise in transport costs. The most frequent of these was to transfer to the least expensive modes at the cost of increased travel times (Diaz Olvera et al., 2010).

Trade-offs between the different modes, whether in the context of intermodal or multimodal practices, take very different forms to those observed in the countries of the North where time is one of the principal parameters of urban life (May et al., 1998) and where time savings are of central importance. The operation of the transport systems in sub-Saharan African cities does not allow time-space compression, which is an extremely important trend in contemporary cities in the developed world (Janelle and Gillespie, 2004). In African cities, price-time trade-offs appear to be very much determined by the extremely low incomes of most public transport users. The result is that city-dwellers have very limited margins of 
manoeuvre with respect to the many constraints that relate to time, finance, or public transport supply.

\section{Conclusion}

Data on daily travel in Lomé allowed us to study practical examples of transport integration. The intermodal and multimodal practices of the city's residents demonstrate that they make a compromise between the external constraints imposed by the way the transport system operates, the location of activities and their personal resources. When they engage in such practices, users incur additional money or time costs, as well as additional physical difficulties, particularly when the modal combination includes long walking segments. The flexibility of motorbike taxis tends to limit the need for intermodal practices in the case of short or medium distance trips. However, for long distance intra-urban trips, such as the trips between the central municipality and the peripheral cantons, the chaining of several modes of transport, motorized or not, becomes inevitable. Intermodal and multimodal practices are equal expressions of how difficult it is for users to pay for their public transport trips and the limited availability of transport in some locations, such as peripheral zones, or at some times of the day or the night.

These findings on intermodality and multimodality in Lomé show that the lack of a public policy to foster integration in the urban transport sector has a major impact on the daily behaviours of the city's residents, in particular those who are poor or who reside in the outskirts. Although individuals may attempt to improvise modal integration using the forms of organization that have been put in place by the operators, functional integration is obviously completely beyond them. Intermodality and multimodality thus involve constant trade-offs between the availability of transport, and the monetary cost and the duration of the trip.

Ambitious forms of integration, for example between transport policies and land-use, or transport policies and policies for other sectors, currently appear to be out of reach for African national and sub-national governments which are frequently politically and economically weak. In a context in which poverty is prevalent, improving accessibility to the resources and opportunities afforded by the city is nevertheless a vital aim for development strategies. Public transport policies that set out to bring about better integration between the various components of transport have an important role to play in achieving this goal (Vasconcellos, 2001; Dimitriou and Gakenheimer, 2011). An integrated transport policy requires that the public authorities play an active role in the organisation and regulation of public transport. Such a policy must be based on a hierarchical transport network which substantiates the complementary nature of the different transport modes (motorized and non-motorized, private and public). Moreover, it requires a "paradigm shift" (Pendakur, 2011: 225) in order to assign a major role to walking that is in line with its actual importance in urban travel in Africa. This change must be accompanied by the willingness to make public transport affordable for lowincome groups. Whatever the local situation regarding the organization of transport in the cities of sub-Saharan Africa, moving towards both modal integration that includes nonmotorized modes and functional integration appear to be essential in order for transport policies to play a role in poverty reduction. 


\section{References}

Audard, F., Perez, J., Webster, L., Grondeau, A., 2012. Système de transport en commun et auto-organisation: Le cas de Brazzaville. Paper presented at the CODATU XV Conference "The role of urban mobility in (re)shaping cities”, Addis Ababa, Ethiopia, October 22-25.

Balbo, M., Navez-Bouchanine, F., 1995. Urban fragmentation as a research hypothesis: Rabat-Salé cases study. Habitat Int. 19(4), 571-582.

Behrens, R., Diaz Olvera, L., Plat, D., Pochet, P., 2004. Meta-analysis of travel of the poor in West and Southern African cities. Paper presented at the $10^{\text {th }}$ World Conference on Transport Research, Istanbul, Turkey, July 4-8.

Behrens, R., McCormick, D., Mfinanga, D., 2012. An evaluation of policy approaches to upgrading and integrating paratransit in African urban public transport systems: results of the first round of a Delphi survey. Paper presented at the CODATU XV Conference "The role of urban mobility in (re)shaping cities", Addis Ababa, Ethiopia, October 22-25.

Cervero, R., 2000. Informal Transport in the Developing World. Nairobi, United Nations Centre for Human Settlements.

Cervero, R., Golub A., 2007. Informal transport: A global perspective. Transp. Policy 14(6), 445-457.

Clifton, K., Muhs, C. D., 2012. Capturing and representing multimodal trips in travel surveys. Transp. Res. Record 2285(1), 74-83.

Diaz Olvera, L., Plat, D., Pochet, P., Sahabana, M., 2010. Quand tout ne tient qu’à un pont ! Réfection d'ouvrage et dysfonctionnements urbains à Douala. Belgéo 2010/1-2, 183-196. Retrieved from http://belgeo.revues.org/6763

Diaz Olvera, L., Plat, D., Pochet, P., 2013. The puzzle of mobility and access to the city in Sub-Saharan Africa. J. Transp. Geog. 32, 56-64.

Dimitriou, H. T., Gakenheimer, R., 2011. Conclusions: emergent crucial themes, in: Dimitriou, H.T., Gakenheimer, R. (Eds.), Urban Transport in the Developing World: a Handbook of Policy and Practice. Edward Elgar, Cheltenham, pp. 589-603.

Gorter, C., Nijkamp, P., Vork, R., 2000. Analysis of travellers' satisfaction with transport chains. Transport. Plan. Techn. 23(3), 237-258.

Givoni, M., Banister, D., 2010. The need for integration in transport policy and practice, in: Givoni, M., Banister, D. (Eds.), Integrated Transport. From Policy to Practice. Routledge, London, pp. 1-11

Guézéré, A., 2008. "Oléyia" (taxi-moto): Acteurs et usagers d’un mode de transport artisanal récent à Lomé (Unpublished doctoral dissertation, Geography). Université de Lomé, Lomé.

Guézéré, A., 2012. Territoires des taxis-motos à Lomé: de la pratique quotidienne à la recomposition des espaces urbains et des liens sociaux. Géographie Économie Société 14(1), 53-72.

Hine, J., Scott, J., 2000. Seamless, accessible travel: users' views of the public transport journey and interchange. Transp. Policy 7, 217-226.

Janelle, D. G., Gillespie, A., 2004. Space-time constructs for linking information and communication technologies with issues in sustainable transportation. Transport Rev. 24(6), 665-677.

Lombard, J., Steck, B., 2004. Introduction. Quand le transport est d'abord un lieu! Autrepart 32, 3-19. Retrieved from http://www.cairn.info/revue-autrepart-2004-4-page-3.htm

Martens, K., 2004. The bicycle as a feedering mode: experiences from three European countries. Transport. Res. A. 9, 281-294.

Martens, K., 2007. Promoting bike-and-ride: the Dutch experience. Transport. Res. A. 41(4), 326-338.

May, A. D., Kelly, C., Shepher, S., 2006. The principles of integration in urban transport strategies. Transp. Policy 13(4), 319-327.

May, N., Veltz P., Landrieu J., Spector, T., 1998. La ville éclatée. Editions de l’aube, La Tour d’Aigues (France). 
McCormick, D., Mitullah, W., Chitere, P., Orero, R., Ommeh, M., 2013. Paratransit business strategies: a bird’seye view of matatus in Nairobi. Journal of Public Transportation 16(2), 135-152.

Ndiaye El Hadji, M., Tremblay, R., 2009. Le transport routier au Sénégal: Problématique de la gestion des gares routières. Can. J. Regional Sci. 32(3), 495-510. Retrieved from http://www.cjrs-rcsr.org/archives/32-3/NDIAYEfinal.pdf

Nkurunziza, A., Zuidgeest, M., Brussel, M., 2012. Modelling commuter preferences for the proposed Bus Rapid Transit in Dar-es-Salaam. Journal of Public Transportation 15(2), 95-116.

Nobis, C., 2007. Multimodality: facets and causes of sustainable mobility behaviour. Transp. Res. Record 2010, 35-44.

Parkhurst,G., Kemp, R., Dijk, M., Sherwin, H., 2012. Intermodal personal mobility: a niche caught between two regimes, in: Geels, F.W., Kemp, R., Dudley, G., Lyons, G. (Eds.), Automobility in Transition? A SocioTechnical Analysis of Sustainable Transport. Routledge, New York, pp. 308-334

Pendakur, V. S., 2011. Non-motorized urban transport as neglected modes, in: Dimitriou, H.T., Gakenheimer, R. (Eds.), Urban Transport in the Developing World: a Handbook of Policy and Practice. Edward Elgar, Cheltenham, pp. 203-231.

Potter, S., Skinner, M. J., 2000. On transport integration: a contribution to better understanding. Futures, 32, 275287.

Preston, J., 2010. Measuring the costs and benefits of integrated transport policies and schemes, in: Givoni, M., Banister, D. (Eds.), Integrated Transport. From Policy to Practice. Routledge, London, pp. 207-222.

Rietveld, P., 2000. Non-motorised modes in transport systems: a multimodal chain perspective for The Netherlands. Transport. Res. D. 5, 31-36.

République togolaise, 2011. Recensement général de la population et de l’habitat. Résultats définitifs. Ministère auprès du Président de la République, chargé de la Planification, du Développement et de l’Aménagement du Territoire.

Rivasplata, C. R., 2001. Intermodal transport centres: towards establishing criteria. Paper presented at the $20^{\text {th }}$ Annual South African Transport Conference, South Africa, July 16-20. Retrieved from http://repository.up.ac.za/bitstream/handle/2263/8173/4b4.pdf?sequence=1

Salon, D., Gulyani, S., 2010. Mobility, poverty, and gender: travel 'choices' of slum residents in Nairobi, Kenya. Transport Rev., 30(5), 641-657.

Sitrass (2004a) Poverty and Urban Mobility in Conakry (Report SSATP nº 09/04/Cky). World Bank, Washington, D.C.: Retrieved from

http://www4.worldbank.org/afr/ssatp/Resources/PapersNotes/Conakry_en.pdf.

Sitrass (2004b) Poverty and Urban Mobility in Douala (Report SSATP n 09/04/Dla). World Bank, Washington, D.C.: Retrieved from

http://www4.worldbank.org/afr/ssatp/Resources/PapersNotes/Douala_en.pdf.

Vasconcellos, E. A., 2001. Urban Transport, Environment and Equity. The Case for Developing Countries. Earthscan, London.

Viegas, J. M., 2004. From multimodality to seamless intermodality in urban transport: a difficult transition. Paper presented at the International Symposium Urban Mobilities: the challenges and research issues in China and abroad, Beijing, China, October 9-11.

Yeh, C. F., 2008. A study on feasability of passenger intermodal transport in city of the developing worl. Paper presented at the Codatu XIII Conference, Ho Chi Minh City, Vietnam, November 12-14. Retrieved from http://www.codatu.org/wp-content/uploads/A-study-on-feasibility-of-passenger-intermodal-transport-in-city-ofthe-developing-world-Chao-fu-YEH.pdf. 